\title{
A cultural studies approach to semantic instability: The case of news translation
}

\author{
Kyle Conway ${ }^{1}$ \\ University of North Dakota (USA)
}

This article explores news translation and the semantic instability of politically charged words and their translations. Such pairs are linked in a paradoxical relationship of dependence (one is a translation of the other) and independence (they have evolved and continue to evolve within different conceptual horizons). This paper describes a methodology for addressing this phenomenon by considering such pairs as examples of 'essentially contested concepts' (Gallie 1956). This methodology derives from a circuit model of culture, and it provides translation studies scholars with tools to describe the dynamic, historically conditioned relationships linking politically charged words, their translations, and their contested, frequently contradictory meanings.

\section{Introduction: news translation}

As the speed of global communication increases, so does academic interest in news translation. "In our multi-lingual, multi-cultural world," writes Susan Bassnett,

information flows through, around, and across language boundaries, and the speed of the flows means that obstacles to communication have to be erased as quickly and smoothly as possible. The processes of global news transfer are extremely complex, and yet the endproduct must be available quickly, efficiently and, insofar as anyone can judge, accurately. (2005: 105)

This recent interest builds on a relatively sparse literature made up of articles published sporadically since the 1970s. They fall into three main groups, the first of which includes articles focusing on international news flow, especially as it is facilitated by international news agencies (e.g. LeeReoma 1978; Wilke \& Rosenberger 1994). The second group, which includes articles by academics and journalists alike, examines the journalist's institutional role in collecting and writing news about people belonging to different cultures, nations, or linguistic groups (e.g. Chu 1984; Goldscheider 2004). The third (and smallest) group of articles compares original texts and their translations (e.g. Abdel-Hafiz 2002; see Bassnett 2005 and Conway \& Bassnett 2006 for recent examples of all three types). 
While we should not underestimate the value of past research, these studies all share a common shortcoming: they all focus on the journalist-astranslator (the two roles are often filled by the same person) as the crucial actor in the processes of meaning-making. Journalists negotiate relationships in foreign cultures, finding fixers who help them meet and interview local people. They act as gatekeepers, deciding what to include and what to omit. They take "translated versions of texts such as official speeches, interviews, witnesses' accounts of facts" and use them "as raw material for the construction of news stories" (Orengo 2005: 173). They are the arbiters, past research tells us, of what foreign news is made available to readers, listeners, and viewers.

This focus on the journalist, however, obscures the role played by other important actors - including those whose speech journalists cite - in attributing meaning to words and events. What is the role of speech writers, to name one example, in shaping the meanings of key politically charged terms, for instance 'war' and 'terror' in George Bush's speeches immediately following the attacks of September 11, 2001 (Montgomery 2006)? What are the roles of public officials, academic experts, and people-on-thestreet? What happens when such terms are translated and reported in a cultural context where they bear a different semantic charge?

Such words and their translations are in fact linked in a paradoxical relationship of dependence and independence: dependence, first, because one is a translation of the other (or, more accurately in some cases, they are translations of each other); and independence, second, because both the word and its translation have evolved within different conceptual horizons. More important, they continue to evolve as journalists and political actors engage in a larger ideological struggle to give them meaning (Conway 2005). Drawing examples from English- and French-language coverage by the Canadian Broadcasting Corporation of the Meech Lake constitutional accord in 1990, this article describes a methodology for addressing this phenomenon of relative semantic instability by considering such pairs as examples of 'essentially contested concepts' (Gallie 1956). This methodology, in contrast to that of past research, shifts focus away from the journalist to the relation of the journalist to the larger social and industrial system. It derives from a cultural studies circuit model of culture, and it provides translation studies scholars with tools to describe the dynamic, historically conditioned relationships linking politically charged words, their translations, and their contested, frequently contradictory meanings.

\section{A more dynamic conception of semantics}

Past research on news translation has treated meaning as one consideration among others that figure in a journalist's decision-making process. Stella Sorby (2006) asks, for instance, how journalists working between Chinese and English account for the approval or disapproval implied by many Chi- 
nese words when English words tend more toward neutrality. What this research has neglected, however, is the historical dimension of meaning how words come to evoke specific associations for different speakers and listeners.

'Meaning' here, to be clear, refers to more than mere denotation (see Hall 1980: 132-133). Instead, it includes the broad, contested set of connotations associated with a word. What a speaker seeks to evoke and what is evoked for a listener may not be the same thing, at which point a certain politics enters the equation: what happens when a word evokes different associations for different people? Whose associations win out when two people or groups of people disagree about what a word means, that is, what it connotes?

Examining this politics involves examining a word and its translation in all of their historical dimensions. As mentioned above, two tools are especially useful in this task: W.B. Gallie's (1956) notion of essentially contested concepts, which provides a vocabulary for describing the complex set of associations (and the tensions between them) evoked by a word, and the circuit model of culture, developed by cultural studies scholars (e.g. Hall 1980; D'Acci 2004) as a means to describe the interactions between competing forces shaping a text, a cultural artifact, or in this case, a word.

\subsection{Essentially contested concepts}

In a paper he delivered to the Aristotelian Society in 1956, W.B. Gallie (1956: 121-122) observed that there existed a class of concepts which, when evoked, were "liable to be contested because of an evident disagreement as to - and the consequent need for philosophical elucidation of [their] proper general use [...]." He went on to argue, however, that for certain concepts, the very idea that there should be a 'proper general use' was misleading:

We find groups of people disagreeing about the proper use of [such] concepts, e.g. of art, of democracy, of the Christian tradition. When we examine the different uses of these terms and the characteristic arguments in which they figure we soon see that there is no one clearly definable general use of any of them which can be set up as the correct or standard use. Different uses of the term 'work of art' or 'democracy' or 'Christian doctrine' subserve different though of course not altogether unrelated functions for different schools or movements of artists and critics, for different political groups and parties, for different religious communities and sects.

Gallie (1956: 125, 131) identified seven traits that characterized concepts such as these, which he described as 'essentially contested': 1) they were evaluative or, in his words, 'appraisive', and 2) the achievement they described was internally complex, 3 ) requiring an explanation that referred to 
the "respective contributions of its various parts or features". 4) The understanding of the achievement could be modified as circumstances changed 5) because everyone using the concept recognized its contested nature. Finally, 6) such concepts referred back to an original exemplar, 7) the understanding of which also developed as people argued about it.

One of Gallie's (1956: 141) stated goals was to shift philosophers' (and linguists') attention away from a conception of meaning informed by the assumptions of classical systems of logic to one informed by hermeneutics or at least historical investigation: "At any given stage in the history of the continued uses of any essentially contested concept, it will no doubt be necessary to call upon psychological or sociological history or the known historical facts of a person's or group's background, to explain their present preferences and adherences." This shift has important implications for questions of cross-cultural communication, and by extension translation, as William Connolly (1974: 38) points out: "When we see the extent to which shared concepts and beliefs enter into our emotional states and actions, it is immediately clear that other societies could populate the world of action and emotion rather differently than we do."

In other words, a concept might be essentially contested in various cultural and linguistic contexts, but contested differently, with groups in each context placing different value on the concept's constituent parts. This situation is further complicated when we consider the relationship of such concepts to language: the associations evoked by the word that names a concept in one language are unlikely to map directly onto the associations evoked by that word's translation in another. As Christina Schäffner (2004: 121) has demonstrated, differences between languages become especially acute in news translation about politics, when journalists or the people they cite make "strategic use of political concepts, or keywords, for achieving specific political aims."

Thus Gallie's conceptual tool raises a larger methodological question, namely how to identify and describe the forces that shape the interpretations and consequent uses made of essentially contested concepts at a given historical moment.

\subsection{Circuit model of culture}

Cultural studies scholars, beginning with those working at the Centre for Contemporary Cultural Studies in Birmingham, England, have proposed various circuit models of culture for dealing with questions such as this. Stuart Hall (1980: 128) was the author of the first (and best known) model, the 'encoding/decoding' model, which borrowed the idea from Marx's Grundrisse that commodity production (in particular, production of television programming) could be studied as a "continuous circuit - productiondistribution-production - [that is] sustained through a 'passage of forms'."

Several scholars have reworked Hall's model, most recently Julie D'Acci (2004), who locates cultural studies' object of analysis in the articulation of 
four discursive sites centered around 1) a cultural artifact, 2) its production, 3 ) its reception, and 4) the relevant socio-historical context.

Concern for context is not new, of course. Schäffner (2004: 137), for instance, observes that "translations (as target texts) reveal the impact of discursive, social, and ideological conventions, norms and constraints. By linking translations (as products) to their social contexts, causes and effects of translations can be discovered [...]." The circuit model goes a step further, however, by directing researchers' attention to the dialectical nature of the relationship of the translator or journalist to the larger social context: translators and journalists, through the texts they produce, have an impact on the very context that shapes their texts in the first place. Hence the circuit. D'Acci (2004: 433) makes this point when she states, first, that her four sites represent points of convergence of "economic, cultural, social, and subjective discourses," and second, that applying the circuit model means describing those discourses in conjunction with the ways the four sites are articulated or linked.

To apply D'Acci's model to words that evoke essentially contested concepts in news and news translation, then, the first step is to identify these four sites:

- Artifact: the word or words in question as they are spoken by political figures, experts, people-on-the-street, etc., and incorporated into news stories

- $\quad$ Production: the work performed by translators and journalists, influenced by their social, institutional, and political roles, as well as by their sense of professional norms, etc.

- Reception: the consumption and interpretation of stories by readers, listeners, and viewers, as influenced by their political, cultural, or other beliefs

- Socio-historical context: the network of other events or issues perceived by translators, journalists, viewers, politicians, etc., as relevant to the events described by journalists in the stories they present

Figure 1 describes these sites as they relate to coverage of the Meech Lake Accord by the Canadian Broadcasting Corporation, discussed in more detail in section 3 (cf. D’Acci 2004: 432).

The second step is to map out the circuit by describing the ways these sites are linked. The questions linking the rectangles in Figure 1 indicate relevant concerns. For instance, how do journalists' roles within a news organization, shaped by their relationships to their editors, to the owners of the organization for which they work, and so on, affect how they incorporate key politically charged words into their stories? How do news consumers' belief systems influence their interpretations of those words in the stories they see, read, or hear? How do news consumers' interpretations in turn, through feedback mechanisms such as television ratings and public opinion polls, influence journalists in their work ${ }^{2}$ 


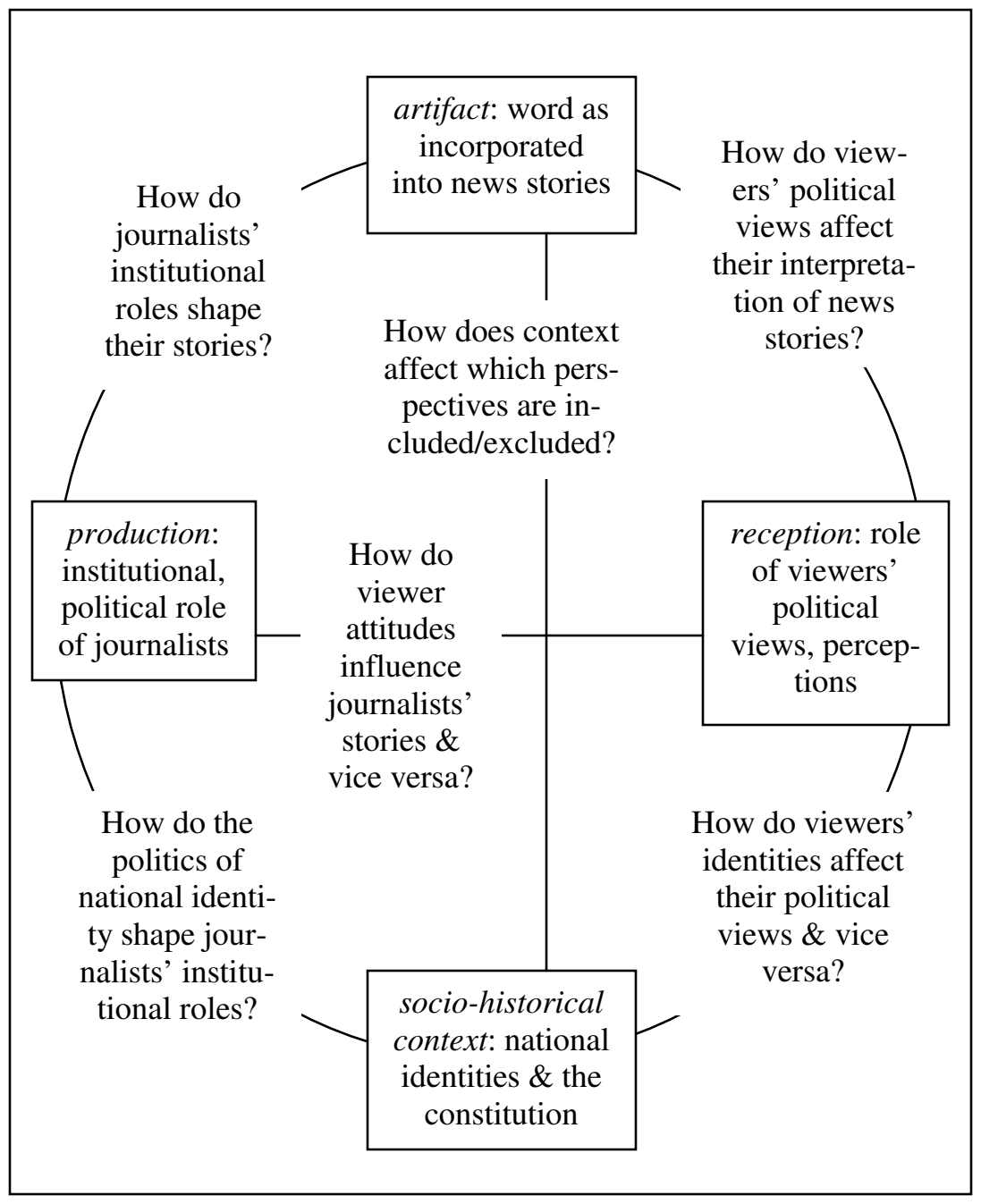

Figure 1: D'Acci's (2004) circuit model applied to coverage of the Meech Lake Accord by the Canadian Broadcasting Corporation

Describing these points of articulation helps clarify how politically charged words, their translations, and the concepts they evoke circulate, making it possible to account for factors beyond those directly related to the journalist that contribute to the processes of meaning-making.

\section{The Meech Lake Accord}

News coverage of the Meech Lake constitutional debates by the Englishand French-language television networks of the Canadian Broadcasting Corporation (the CBC and Radio-Canada, respectively) offers a good illu- 
stration of the dynamics shaping the circulation of politically charged words and their translations. The Meech Lake Accord, reached by Canada's federal and provincial leaders in 1987, was designed to create the political conditions necessary for the French-speaking province of Québec to join the Canadian constitution. Québec had refused to ratify the constitution since 1982, when then-Prime Minister Pierre Trudeau patriated it from London to Ottawa without first agreeing upon an amendment formula that Québec found acceptable. As part of the 1987 agreement, Québec sought recognition as a 'société distincte' or 'distinct society', along with the legal entrenchment of various rights related to its ability to veto future amendments, to appoint judges to the Supreme Court, and to regulate its own immigration.

Not surprisingly, the terms 'société distincte' and 'distinct society' were controversial, especially outside of Québec, where many people feared that such recognition would give the province undue special powers (IRPP 1999: 315-324). This fear arose largely from the fact that the terms were not explicitly defined in the Meech Lake Accord. As a result, it was difficult, if not impossible, to identify a clearly delineated meaning at the denotational level - even the terms' denotations were actively contested. Hence the analytical utility of Gallie's notion of essentially contested concepts. The terms 'société distincte' and 'distinct society' were clearly evaluative, describing Québec's place in Canada, with people approving or disapproving largely as a function of whether they were sympathetic toward Québec (trait 1). The qualities they described were complex. Historians such as Brian O'Neal (1995) cite the preliminary report of the Royal Commission on Bilingualism and Biculturalism in 1965 as the place where the terms as such first appeared (earlier reports had evoked Québec's specificity using other terms). The commission described Québec's 'société distincte'/'distinct society' in largely sociological terms, pointing to the province's use of the French language, its civil law tradition, and its distinct educational and economic institutions. As debate about the constitution and Québec's place in Canada continued through the 1970s and 80s, the terms came to resonate also on emotional, legal, and political registers, depending on the circumstances (Behiels 1989). People participating in the debates leading up to Meech Lake gave different weight to different aspects, and, consequently, the way the terms were understood effectively evolved (traits 2-5). At the same time, people appealed to exemplary (if contradictory) notions of federalism and sovereignty to make their case, fueling debate about these concepts as well (traits 6-7).

The following sections apply D'Acci's (2004) circuit model framework to coverage of the Meech Lake Accord in its final days. When Canada's leaders reached the accord in 1987, they stipulated that it must be ratified by all provincial legislatures within three years. By 1990, Newfoundland and Manitoba had yet to do so, even as the June 23 deadline approached. Newfoundland premier Clyde Wells was elected after the 1987 agreement was reached. Unlike his predecessor, he opposed Meech Lake, 
and he chose not to bring it forward for a vote in Newfoundland's legislature. In Manitoba, Elijah Harper, a Native member of the provincial legislative assembly, used parliamentary procedures to block a necessary vote because he felt that the accord marginalized Native concerns. When it failed to pass these two legislatures, Canadian leaders declared the agreement dead.

The following analysis describes the circulation of the terms 'société distincte' and 'distinct society' on Radio-Canada and the CBC. It highlights the terms' internally complex nature by foregrounding those aspects that speakers chose to evoke during Meech Lake's final days. Sections 3.1 and 3.2 describe the artifacts themselves: 'société distincte', 'distinct society', and the meanings they evoked on the flagship nightly news programs of Radio-Canada (Le Téléjournal) and the CBC (The National). Section 3.3 examines points of articulation between discursive sites, in particular the effect of viewer attitudes (3.3.1 and 3.3.2) and socio-historical context (3.3.3) on the terms' meanings.

\subsection{Artifact one: 'Société distincte' on Le Téléjournal}

Between June 9, 1990, the day Canada's federal and provincial leaders reached a last-minute compromise in hopes of ensuring Meech Lake's passage, and June 25, two days after the deadline to pass it, Le Téléjournal and The National each produced sixty-three stories about the accord. Because the terms had not been explicitly defined, the difference in meaning between 'société distincte' and 'distinct society' as they were used on the two programs derived from the connotative associations that each evoked. On the French-language program, speakers sought to evoke associations related to Québécois culture: 'société distincte' described a province with its own political and social institutions where French was the majority language, the implication being that rejecting the accord with its 'société distincte' clause was tantamount to refusing to recognize Québec and its rightful place in the Canadian confederation. By appealing to Québec nationalism in this way, speakers inflected the sociological aspects of 'société distincte' with political and emotional overtones. (In contrast, speakers on The National sought to limit the meaning of 'distinct society' to a clause in the Meech Lake Accord, rather than Québécois culture per se, the implication being that it was possible to reject the accord while still recognizing Québec's value in the larger Canadian context.)

Stories about Québec figured prominently on Le Téléjournal. There were fourteen, a number equaled only by the number of stories about Manitoba and Elijah Harper. In its Québec stories, where the 'société distincte' was most frequently discussed, Le Téléjournal focused on the province's politicians, and as a result, the term 'société distincte' evoked strongly political associations, shaped by the maneuvering politicians had to do to arrive at an agreement. Journalists and the people they interviewed continually asked what Québec's politicians had to give up in exchange for 
Québec's recognition as a 'société distincte': did Premier Robert Bourassa give up too much?

Coverage of Bourassa's interactions with Jacques Parizeau, leader of the Parti Québécois (PQ), which acted as official opposition in Québec's legislative Assemblée nationale, provides a representative example of how political confrontations combined with emotional appeals to shape the associations evoked by 'société distincte' on Le Téléjournal. Night after night, Parizeau criticized Bourassa for having given up too much. On June 10, for example, reporter Marthe Blouin paraphrased Parizeau, saying, "Selon le chef du PQ, l'accord du Lac Meech est copieusement amendé, et la notion de 'société distincte' substantiellement diluée par l'avis juridique qui est annexé" [According to the PQ leader, the Meech Lake Accord has been copiously amended, and the notion of 'société distincte' substantially watered down by the appended legal opinion]. Then Parizeau himself, reproaching Bourassa for feeling a stronger connection to Canada than to Québec, said, "M. Bourassa a lâché en dépit de tous les messages qu'on pouvait lui passer. Il a lâché pour garder son pays" [Mr. Bourassa gave up despite all the messages we could send him. He gave up in order to preserve his country]. Then, June 11 - Bourassa and Parizeau participated in a debate during which Parizeau accused Bourassa of having caved in. June 12 Bourassa was forced yet again to demonstrate that he had not given in; a group calling itself Les Amis de Meech [Friends of Meech] rose to his defense. Only at the end of the debates did Parizeau relent, reaching his hand out in a symbolic gesture to a defeated and angry Bourassa on Le Téléjournal on June 22, the day it became clear that neither Manitoba nor Newfoundland would hold a vote. His tone after that point was conciliatory, but apparently only because Bourassa seemed to adopt a position closer to his own. Meech Lake's defeat, according to a June 24 story about a meeting between Bourassa and his provincial counterparts, could be seen only as a repudiation of Québec and its concerns, whose legitimacy derived from the province's status as a 'société distincte'.

\subsection{Artifact two: 'Distinct society' on The National}

In contrast to Le Téléjournal, The National framed stories about recognition of Québec as a 'distinct society' in terms that carefully circumscribed its meaning. For one thing, reporters for The National de-emphasized the Québec political context (and the bitterness that characterized it). For another, the program featured more stories about politicians from Ottawa, a total of eleven, than from Québec, a total of seven.

In concrete terms, this meant that Parizeau did not play as large a role as on Le Téléjournal. The June 11 edition of The National, for instance, featured a story about Bourassa's triumphant return to Québec's legislature after reaching the last-minute compromise two days earlier. Reporter Paul Workman explained, "Robert Bourassa received a long and jubilant welcome as he returned to the Québec National Assembly." As he spoke, The 
National showed images of the members of the legislature standing and applauding. Not that Parizeau was absent, of course. Workman further explained, "Among the few not standing were members of the Parti Québécois, who accused the premier of selling out Québec's best interests." Parizeau then held up a list of amendments that had been added to the agreement, but his objections did not shift the focus away from Bourassa's optimism.

The focus on federal politicians also shaped the meaning of 'distinct society' on The National. In contrast to their Québec counterparts, federal politicians explained the rejection of Meech Lake by appealing to national unity and by insisting that the accord's failure did not imply a rejection of Québec. The exception was Joe Clark, one of Prime Minister Brian Mulroney's cabinet members, who asked of Clyde Wells's decision not to hold a vote, "How can you convince Quebecers that this is not a rejection? Of course this is a rejection by some Canadians of Québec - it can be seen as nothing else" (June 22). Other than Clark, however, federal politicians followed the cue of Mulroney, who reacted to the accord's death by saying, "It's a sad day for Canada. This was all about Canada, about the unity of our country" (June 22), a sentiment he echoed in a speech the next day: "To my fellow Quebecers, I want to say how dismayed I am that Québec has not at this time been able to join the constitutional family" (June 23). Senator Lowell Murray made the link between this line of reasoning and the "distinct society' clause explicit when he proposed that "so far as the federal government is concerned, we're going to have to find ways - there are ways - many ways outside of the constitutional discussions to respect the distinctiveness of Québec in all our policies and programs" (June 23). In this way, most speakers on The National worked to limit the term 'distinct society' to the clause itself, rather than applying it to the whole of Québécois culture and identity.

\subsection{Points of articulation}

\subsubsection{Viewer attitudes in the context of reception}

A large and well established literature has demonstrated that English Canadians' and Francophone Quebecers' interpretations of Canadian history and Canadian federalism diverge significantly, especially in the ways they understand the provinces' relationships with each other and with the federal government in Ottawa. English Canadians typically see all provinces as equal, while Quebecers typically see Québec as home to one of two 'founding peoples' (IRPP 1999; Gagnon \& Iacovino 2007). Because of these divergent interpretations, viewers of The National did not generally share a common interpretive framework with viewers of Le Téléjournal. During the final days of the Meech Lake Accord, these different conceptions, amplified by the strong emotions generated by the highly charged debate, became manifest in the following ways. In Québec, feelings of nationalism in- 
creased, in no small part because of Quebecers' perceptions of hostility from the rest of Canada. According to a May 1990 poll, 65 percent of Quebecers found the rest of Canada hostile toward their province. A majority also thought they were better governed by the provincial government in Québec City than Ottawa, and, consequently, preferred Québec politicians to federal politicians (Bissonnette 1990: 9).

A certain bitterness was apparent among English Canadians, too. The same poll confirmed, first of all, that most Canadians outside of Québec (73 percent) viewed themselves as Canadian citizens first, residents of their province second. More than half felt that the country was more divided than it had been five years before, and, perhaps not surprisingly, Québec was the region with which they felt the least affinity (Bissonnette 1990: 13). Despite this "profound lack of sympathy" (Allan Gregg, quoted in Bissonnette 1990: 13), nearly three quarters of Canadians outside of Québec said that they did not want the province to separate. While English Canadians wanted unity, however, they wanted it on their own terms. In a different poll, 53 percent of English Canadians supported the Meech Lake Accord when it was described as allowing Québec to rejoin the constitutional family; 56 percent opposed it when it was described as recognizing Québec as a 'distinct society' (Blais \& Crête 1991: 389).

\subsubsection{The impact of viewer attitudes on production}

These divergent attitudes begin to explain some of the differences between the two programs' coverage. To explain how audience worldviews and expectations shape the way journalists report the news, Mohammed elNawawy and Adel Iskandar (2003: 54) have proposed the concept of 'contextual objectivity' - "the necessity of television and media to present stories in a fashion that is both somewhat impartial yet sensitive to local sensibilities". Such a necessity was apparent in the case of Meech Lake, where there was a clear congruence between the widespread perception in Québec of English Canadian hostility and the recurrent assertion on Le Téléjournal that a rejection of Meech Lake was also a rejection of Québec. Likewise for English Canadians' rather ambivalent attitude toward Québec expressed in their desire for la belle province to remain part of Canada - but on Canada's terms - and The National's coverage of the English Canadian political elite contending that Canada still valued Québec despite Meech Lake's failure. In both cases, journalists were arguably taking viewers' interpretations of events into account, even as the stories they produced worked to reinforce them.

\subsubsection{The role played by socio-historical context}

An important aspect of context that helps explain these differences has to do with how news programs achieve balance. According to the Journalistic Policy guidebook of the Canadian Broadcasting Corporation (1988: 7), 
"programs dealing with matters of public interest on which differing views are held must supplement the exposition of one point of view with an equitable treatment of other relevant points of view." Context plays a crucial role in shaping journalists' judgments about who should be called upon to express the "other relevant points of view". In the case of Meech Lake, who should respond, for instance, when Robert Bourassa speaks in favor of the accord - Jacques Parizeau, whose disagreement with Bourassa is grounded in provincial politics, or Clyde Wells, whose disagreement is grounded in federal politics?

According to Trina McQueen (1990), the CBC's vice president of news in 1990, the mandate for balance was one that $\mathrm{CBC}$ journalists took very seriously, despite the accusations of bias that followed in the wake of Meech Lake's demise (see Boswell 1991). The problem faced by Englishlanguage journalists was that the majority of federal and provincial politicians favored the accord, but voters outside of Québec were increasingly disenchanted with it. To maintain balance, journalists had to seek out the accord's political detractors; as a result, between January and June 1990, "Clyde Wells appeared on The National and The Journal [the CBC's flagship public affairs program] 69 times, well ahead of the second most interviewed leader, Robert Bourassa, who was on 45 times" (McQueen 1990: A27; see also Alboim 1988).

The effect of political and social context on who responded to whom was just as strong on Le Téléjournal. The person who spoke most between June 9 and June 25 was Robert Bourassa, who spoke in ten different stories. In seven of those stories, he was the person whose speech was responded to (the rest of the time, he was a respondent). The person who responded to Bourassa the most times was Jacques Parizeau. Likewise, Parizeau was the person Bourassa responded to the most times. (On The National Bourassa spoke eight times, and his only respondent was Clyde Wells.) It is not surprising, then, that the meaning of 'société distincte' was so politically charged on Le Téléjournal: the people whom journalists chose to respond to the accord's biggest proponent in Québec were his political rivals. The semantic charge of 'distinct society' on The National was different: the accord's supporters and detractors both had more room to maneuver, and

their sense of national identity was not invested in the recognition of Québec's specificity in the same way as Québec's sense of itself.

\section{Conclusion}

We could expand our examination to look at other points of articulation indicated in Figure 1; the influence of the politics of national identity on journalists' and translators' approaches to their work, and the resulting impact on the meanings of 'société distincte' and 'distinct society', would be especially useful to map out. Expanding our scope, as even the limited analysis in this article suggests, would reveal that while these terms ap- 
peared to be semantic equivalents (and were treated as such by journalists, for instance, when they gave voiceover translations of politicians speaking a language their viewers did not speak), they circulated differently on The National and Le Téléjournal. Journalists were actors in the very same political systems about which they were reporting, and as a result, they did not necessarily have the perspective to recognize and describe the ways the terms meant different things to different groups. Thus it would not necessarily have been clear to viewers that they meant different things. The end result was that Canada's English- and French-speakers were talking past each other as the Meech Lake Accord fell apart. The news services of the $\mathrm{CBC}$ and Radio-Canada were not solely responsible for this failure to communicate, of course. Rather, their coverage was symptomatic of a larger cultural disconnect between Canada's linguistic communities: as the circuit model makes clear, their coverage both reacted to and reinforced an already existing semantic gap between 'société distincte' and 'distinct society'.

We can draw a second conclusion here, too, which relates to the methodology proposed in this paper. It is worth investigating whether this methodology has applications in other contexts and disciplines. It promises, for instance, to yield new insight into situations such as those described by Schäffner (2004) where journalists and translators have different levels of choice between words when translating. Likewise, it should be able to accommodate approaches deriving from political science, history, media studies, and so on. It should also be able to make use of quantitative approaches (e.g. statistical content analysis) as well as qualitative approaches (e.g. cultural history). In this way, it should be applicable to more than just news translation, and it stands to shed new light on the historically conditioned relationships linking semantics, translation, and the circulation of meaning. 


\section{Bibliography}

Abdel-Hafiz, Ahamd-Sokarno (2002). "Translating English Journalistic Texts Into Arabic: Examples from the Arabic Version of Newsweek". International Journal of Translation 14(1), 79-103.

Alboim, Elly (1988). "Inside the News Story: Meech Lake as Viewed by an Ottawa Bureau Chief". Roger Gibbins (ed.) (1988). Meech Lake and Canada: Perspectives from the West. Edmonton: Academic Printing and Publishing, 235-245.

Bassnett, Susan (ed.) (2005). Global News Translation. Clevedon/Buffalo: Multilingual Matters. Special issue of Language and Intercultural Communication 5(2).

Behiels, Michael D. (ed.) (1989). The Meech Lake Primer: Conflicting Views of the 1987 Constitutional Accord. Ottawa: University of Ottawa Press.

Bissonnette, Lise (1990). “Où va le Québec?" L'Actualité, 1 May, 7-13.

Blais, André \& Jean Crête (1991). "Pourquoi l'opinion publique au Canada anglais a-t-elle rejeté l'Accord du lac Meech?" Raymond Hudon \& Réjean Pelletier (eds) (1991). L'Engagement intellectuel: mélanges en l'honneur de Léon Dion. Sainte-Foy: Presses universitaires de l'université Laval, 385-399.

Boswell, Randy (1991). "Duel Over CBC 'Bias'”. Content, May-June, 11.

Canadian Broadcasting Corporation (1988). Journalistic Policy. Ottawa: Canadian Broadcasting Corporation

Chu, James (1984). "The Gathering of News About China". Gazette 33, 87-106.

Connolly, William E. (1974). The Terms of Political Discourse. Lexington: D.C. Heath.

Conway, Kyle (2005). "Assessing Apparently Equivalent Translations in the News Media". Meta 50(4). On-line at www.erudit.org/livre/meta/2005/000201co.pdf.

Conway, Kyle \& Susan Bassnett (eds) (2006). Translation in Global News: Proceedings of the Conference Held at the University of Warwick, 23 June 2006. Warwick Working Papers. Coventry: University of Warwick Centre for Translation and Comparative Cultural Studies.

D'Acci, Julie (2004). "Cultural Studies, Television Studies, and the Crisis in the Humanities". Lynn Spigel \& Jan Olsson (eds) (2004). Television After TV: Essays on a Medium in Transition. Durham: Duke University Press, 418-445.

Gagnon, Alain-G. \& Raffaele Iacovino (2007). Federalism, Citizenship, and Quebec: Debating Multinationalism. Toronto: University of Toronto Press.

Gallie, W.B. (1956). "Essentially Contested Concepts". Max Black (ed.) (1962). The Importance of Language. Englewood Cliffs: Prentice Hall, 121-146.

Goldscheider, Eric (2004). "Found in Translation". Boston Globe Magazine, 24 October. On-line at www.boston.com/news/globe/magazine/articles/2004/10/24/found_in_translation.

Hall, Stuart (1980). "Encoding/Decoding". Stuart Hall et al. (eds) (1980). Culture, Media, Language. London: Hutchinson, 128-138.

IRPP (Institute for Research on Public Policy) (ed.) (1999). As I Recall/Si je me souviens bien: Historical Perspectives. Montréal: IRPP.

Lee-Reoma, Siu-Chu (1978). "The Translation Gap and the Flow of News". WACC Journal 25(1), 13-17.

McQueen, Trina (1990). "How the CBC Covered Meech Lake”. Toronto Star, 25 July, A27.

Montgomery, Martin (2006). "Semantic Asymmetry and the 'War On Terror"'. Conway \& Bassnett (2006), 23-28.

el-Nawawy, Mohammed \& Adel Iskandar (2003). Al-Jazeera: The Story of the Network That Is Rattling Governments and Redefining Modern Journalism. Boulder: Westview Press.

O’Neal, Brian (1995). "Distinct Society: Origins, Interpretations, Implications". Library of Parliament Background Paper BP-408E. Ottawa: Parliamentary Research Branch.

Orengo, Alberto (2005). "Localising News: Translation and the 'Global-National' Dichotomy". Bassnett (2005), 168-187.

Schäffner, Christina (2004). "Political Discourse Analysis from the Point of View of Translation Studies". Journal of Language and Politics 3(1), 117-150.

Sorby, Stella (2006). "Translating News from English to Chinese: Complimentary and Derogatory Language Usage". Conway \& Bassnett (2006), 113-126.

Taras, David (1991). "How Television Transformed the Meech Lake Negotiations". Electronic Journal of Communication 1(2). On-line at www.cios.org/www/ejc/v1n291.htm. 
Wilke, Jürgen \& Bernhard Rosenberger (1994). "Importing Foreign News: A Case Study of the German Service of the Associated Press". Journalism Quarterly 71(2), 421-432.

1 The author would like to thank the Délégation du Québec à Chicago (Ministère des relations internationales) and the International Council for Canadian Studies for the funds they provided that made this research possible. He would also like to thank participants at the TransCanada Two conference (Guelph, Ontario, October 14, 2007) and the Association for Canadian Studies in the United States biennial conference (Toronto, Ontario, November 15, 2007) for their feedback on earlier versions of this paper. Finally, he would like to thank the journal's two anonymous reviewers for their clear-sighted recommendations.

2 With more space, we could expand the scope of the analysis sketched out here in at least two ways. First, we could look at other factors influencing the meaning of specific terms as they circulate in news discourse. For instance, during the Meech Lake debates described in section 3, politicians were also news consumers, as were journalists themselves. Politicians frequently made statements in direct response to coverage of the Meech Lake debates (see Taras 1991). Evidence also suggests that journalists shaped their stories in reaction to what they were seeing or hearing from other news organizations. Second, we could explore the implications of a factor that further complicates the analysis of politically charged words and their translations. Clearly, the members of such pairs circulate as artifacts within their own respective linguistic contexts. We could, therefore, apply the circuit model schema described here twice, once for a word, once for its translation. However, the journalist's act of translation brings these contexts into contact. As a result, the distinction between these two applications becomes blurred, requiring us to consider how the passage from one context to the other alters the circulation of such words within their own respective linguistic worlds.

3 The equivalence of 'distinct society' and 'société distincte' was sanctioned by the terms' use in the English and French versions of the Meech Lake Accord. Because they were the official terms, journalists were constrained in their lexical choice when translating them for viewers, listeners, or readers (cf. Schäffner 2004: 121-124). Despite their sanctioned equivalence, however, they still evoked different associations in English and in French. It is in cases like this, where the journalist's lexical choice is limited, that the circuit model, with its focus on the relation of the journalist to the larger social and political context, yields insight that would be missed by methodologies with a narrower focus on journalists and the choices they make. 